\title{
Heat Tolerance of Kentucky Bluegrasses, Perennial Ryegrasses, and Annual Bluegrass ${ }^{1}$
}

\author{
D. J. Wehner and T. L. Watschke ${ }^{2}$
}

\begin{abstract}
Use of cool-season turfgrasses in transitional environments is limited, in part, by their heat tolerance. Development of a rapid heat tolerance screening technique would be of value in determining the potential of turfgrasses for use in warmer areas.

The heat tolerance of 22 Kentucky bluegrass (Poa pratensis $\mathbf{L}$.) cultivars, Poa amnua $\mathrm{L}_{\text {., }}$ and four perennial ryegrass cultivars (Lolium perenne $\mathbf{L}$.) was evaluated by exposing plants for $30 \mathrm{~min}$ to temperatures ranging from 41 to $49 \mathrm{C}$ in single degree intervals. Ten-week-old plants, which had been grown under a low level of $\mathbf{N}$ fertilization and watered infrequently to maximize heat tolerance development, were sealed in plastic bags, placed in a constant temperature water bath for treatment, and then replanted. Recovery was evaluated by visually rating the plants 4 weeks after treatment or by harvesting and weighing plants 2 weeks after treatment and expressing the weight as a percentage of the weight of a nonstressed control (referred to as recovery weight). Cultivar com. parisons were based on the average recovery weight over a given temperature range.

Initial injury occurred at 41 to $43 \mathrm{C}$ with complete kill at 47 to 49 C. Kentucky bluegrass was more heat tolerant than Poa annua $\mathbf{L}$. and perennial ryegrass. Heat tolerance of the latter two species was approximately equal. The Kentucky bluegrass cultivars tested were similar in heat tolerance. Among the ryegrasses, 'Loretta' was less heat tolerant than 'Diplomat', 'Pennfine', and 'Citation'. Of all the grasses, 'Sydsport' Kentucky bluegrass ranked the highest and Loretta perennial ryegrass the lowest in heat tolerance. The correlation between dilute acid extractable carbohydrate reserves and recovery weight for these five cultivars was not significant. There was a significant negative correlation between recovery weight and $\mathrm{Fe}$ and $\mathrm{Al}$ concentration.
\end{abstract}

Additional index words: Heat stress, Stress recovery, Carbohydrates, Mineral analyses, Poa pratensis L., Lolium perenne L., and Poa annua $\mathrm{L}$.

$\mathbf{M}^{A}$ ANAGING cool-season grasses for recreational turf in transitional areas is difficult. Heat stress often reduces turf quality when recreational facilities are receiving maximum use. In the short term, reducing $\mathrm{N}$ and water applications induces a "hardened" turf. The long term solution to the problem lies in identifying and incorporating heat tolerant germplasm into breeding programs. Currently available cultivars need to be screened for heat tolerance followed by studies into tolerance mechanisms.

The optimum temperature for shoot growth of coolseason turfgrasses is in the range 15 to $24 \mathrm{C}$ (Beard, 1973). Above $24 \mathrm{C}$, growth subsides first and then at very high temperatures, severe injury or death can occur. In controlled environment pot experiments, Kentucky bluegrass (Poa pratensis L.) produced maxi-

\footnotetext{
${ }^{1}$ Contribution from the Dep. of Agronomy, The Pennsylvania State Univ, University Park, PA 16802.

${ }^{2}$ Former graduate student, Dep. of Agronomy, The Pennsylvania State Univ. (currently assistant professor of agronomy, Univ. of Illinois, Urbana, IL); associate professor of turfgrass science, The Pennsylvania State Univ., University Park, PA 16802.
}

mum dry weight of top growth at 21.6 C, and growth declined as temperature was increased to $24.9 \mathrm{C}$, Baker and Jung (1968). Plants grown at $34.8 \mathrm{C}$ produced less than half the top growth of those at $21.6 \mathrm{C}$. Julander (1945) observed that Kentucky bluegrass was killed when exposed to $48 \mathrm{C}$ for 16 hours.

Indirect injury from exposure for prolonged periods of moderately high temperature, or direct injury due to short periods (30 minutes or less) of very high tem. perature may occur (Levitt, 1972). The relative importance of the two in turfgrass culture is not known. Several studies have been done on the influence of prolonged periods of moderately high temperature on turfgrass growth (Baker and Jung, 1968; Watschke et al., 1972; Pellett and Roberts, 1963). Less information is available on the effects of short exposure to high temperature.

Factors which influence heat tolerance are plant age, management, season, water status, and environment (Lange, 1965). Evaluation of plants for heat tolerance needs to be done in the presence of $100 \%$ relative humidity to insure that transpirational cooling does not lower plant tissue temperature (Kinbacher, 1963). Lange (1965) recommended immersing plants in a water bath for $30 \mathrm{~min}$ and observing recovery several days later. He stated that plant temperature rapidly equilibrates with the water temperature unless the plant has a high water content or thick leaves.

The effects of both water (Julander, 1945) and N fertilizer (Carroll, 1943) management on the heat tolerance of turfgrasses has been studied. Frequent irrigation reduced the differences in heat tolerance between warm-and cool-season grasses that were found when they were watered infrequently (Julander, 1945). High rates of applied $N\left(3.05 \mathrm{~kg} \mathrm{~N} / 100 \mathrm{~m}^{2}\right)$ reduced heat tolerance of cool-season turfgrasses when compared to low rates of $\mathbf{N}$ (no applied $\mathbf{N}$ ) (Carroll, 1943). Pellet and Roberts (1963), working with Kentucky bluegrass in solution culture, reported that balanced nutrient levels were necessary for maximum heat tolerance.

Most of the literature concerning heat stress of grasses deals with species comparisons (Carroll, 1943; Julander, 1945). Beard (1973) ranked the heat tolerance of 19 turfgrasses. Kentucky bluegrass was classified as having medium heat tolerance while perennial ryegrass (Lolium perenne L.) and Poa annua were classified as having fair heat tolerance. A 2 hour exposure to a tissue temperature of $42 \mathrm{C}$ has been shown to be lethal to Poa annua (J. A. Fisher, 1967. An evaluation of high temperature effects on annual bluegrass (Poa annua L.) M.S. Thesis, Michigan State University, East Lansing.)

The objective of this research was to evaluate the heat tolerance of several cultivars of Kentucky bluegrass, and perennial ryegrass, and Poa annua, using 30 min exposure to high temperatures. 


\section{MATERIALS AND METHODS}

\section{Plant Material}

The cultivars evaluated in this study and their sources are listed in Table 1. Selection of these cultivars was based on one or more of the following criteria: 1) cultivars that were felt to be heat tolerant by breeders or other individuals who had been asked to supply material for the study; 2) cultivars that were considered economically significant in terms of commercial seed production; 3) origin of selections; and 4) cultivars that were reported as generally high or low in quality in the "Northeastern Regional Turfgrass Evaluation of Kentucky Bluegrasses (Poa pratensis L.) 1968-1973" (1977). A native Poa annua L. was included for comparison. Seeds of each cultivar were obtained directly from the breeder responsible for development of the cultivar or from proprietary contractors who were considered the best source of authentic samples. The seed was planted in $11 \mathrm{~cm}$ pots containing Hagerstown silt loam soil (fine, mixed, mesic Typic Hapludalf) with a pH of 7.0 and 93 and $325 \mathrm{~kg} / \mathrm{ha}$ available $\mathrm{P}$ and $\mathrm{K}$, respectively. After 6 weeks, the plants were thinned to 60 plants per pot. These plants were the starting material for the experiments described later. In all the experiments, the plants were regularly clipped to a height of $5 \mathrm{~cm}$.

\section{Procedure for Imposing Heat Stress}

Plant material grown as described for each experiment was exposed to heat stress in the following manner. Plants were removed from soil, stripped of dead leaves, and the root system trimmed to the base of the crown. They were then placed in 15 $\mathrm{cm}$ by $15 \mathrm{~cm} 4$-mil plastic bags (five plants per bag) containing approximately $5 \mathrm{ml}$ of water. Each bag was pressed flat to remove as much air as possible, sealed, and clipped to a wire rack. The rack was immersed in a constant temperature ( \pm $0.1 \mathrm{C})$ water bath for $30 \mathrm{~min}$. Treatment temperatures ranged from 41 to $49 \mathrm{C}$ in one degree intervals and was measured with a mercury thermometer $( \pm 0.2 \mathrm{C})$. Three to six replications were run for each experiment as follows. One pot of each cultivar was used for all treatments in a replication. For each pot, five plants were pulled, sealed in a bag, treated at $41 \mathrm{C}$, and replanted. The bath temperature was then increased to $42 \mathrm{C}$ and the next set of plants was treated and this procedure continued until the entire temperature range was covered.

After heating, the plants were replanted in Jiffy-mix $(50: 50$ peat and vermiculite) and placed in the greenhouse for recovery. Recovery was assessed either by visually rating the plants in comparison to controls (plants that had been treated in the same manner except were heated at $27 \mathrm{C}$ ) or by determining the dry weight of the recovered plants and expressing it as a percentage of the weight of the control. When ratings were used, each plant was rated on a scale of 1 to 5 with 1 equivalent to a dead plant and 5 equal to little or no injury. The average of five plants (five plants per replication at each temperature) was used for statistical calculations. When weights were used two sets of controls were run for each replication (one before the start of the temperature series and one after completion). The total dry weight of the five treated plants (whole plant) was divided by the weight of the control (average of two sets of controls) and the result expressed as a percentage.

A randomized complete block design with a factorial analysis was used. The main factors were cultivars and temperatures. The responses of the plants to heat was sigmoidal with no injury between 27 to $40 \mathrm{C}$ and complete kill above $49 \mathrm{C}$. The data from the temperature range for the linear portion of the response curve for each experiment was used for the analysis. The cultivar by temperature interaction was not significant ex. cept as noted in the results section. Therefore, cultivar means over all temperatures were used for comparisons. Duncan's Modified Least Significant Difference Test (Waller and Duncan, 1969 ) with $\mathrm{k}=100$ was used to compare the means.

\section{$\mathbf{N}$ and Water Study}

Six-week-old plants of four Kentucky bluegrasses and Poa annua were divided into two groups (three replications per group) and placed in a growth chamber. The chamber was set for a $27 / 16 \mathrm{C}$ day/night temperature regime with a 12 hour photoperiod (285 $\mu \mathrm{Em}^{-2} \mathrm{~s}^{-1}$ ) at pot level. One group (low maintenance) received an application of $37 \mathrm{mg}$ of $\mathrm{NH}_{4} \mathrm{NO}_{3}(11.8$ $\mathrm{kg} \mathrm{N} / \mathrm{ha}$ ), watered to a weight reflecting $26 \%$ soil moisture, and allowed to dry to $11 \%$ soil moisture before rewatering. The other group (intensive maintenance) received four weekly applications of $74 \mathrm{mg} \mathrm{NH} \mathrm{NO}_{3}$ total of $94.4 \mathrm{~kg} \mathrm{~N} / \mathrm{ha}$ ) and was maintained at approximately $26 \%$ soil moisture. The plants were kept in the growth chamber for 4 weeks with each pot being weighed daily and watered accordingly. Twenty-four hours prior to the stress test, pots in the low maintenance group within each replicate were brought to the same weight (approxi. mately $18 \%$ soil moisture). This was done to minimize the variation in soil moisture among pots when the plants were being removed for the stress test. After the stress test, the plants were placed in a greenhouse and rated for recovery 4 weeks later. The results of the experiment were based on observation of 1,050 plants (three replications).

\section{Screening of Greenhouse Grown Bluegrasses}

Two sets of 12 Kentucky bluegrasses (three replications per set), started 1 week apart, were grown in the greenhouse. When each set was 6 weeks old, the plants were thinned, fertilized with $37 \mathrm{mg}$ of $\mathrm{NH}_{4} \mathrm{NO}_{3}$, and brought to $26 \%$ soil moisture. Pots were allowed to dry to $11 \%$ soil moisture before watering. The plants were maintained in the greenhouse for 5 additional weeks with the weight of the pots checked daily. The average daily high and low temperatures in the greenhouse were 24.4 and $20 \mathrm{C}$, respectively. Twenty-four hours prior to the stress test, the pots within each replication were brought to approxi. mately the same weight. The plants were exposed to the stress test, replanted, allowed to recover in the greenhouse for 4 weeks, and then rated for recovery. The average high and low temperatures for the recovery period for Set 1 were 24.7 and $18.5 \mathrm{C}$, respectively. The average high and low temperatures for the recovery period for Set II were 25.7 and $19 \mathrm{C}$, respectively. The results of this experiment were based on observation of 2,520 plants.

Table 1. Bluegrass and ryegrass cultivars evaluated and their proprietary source.

\begin{tabular}{ll}
\hline Cultivar & \multicolumn{1}{c}{ Proprietary source } \\
\hline \multicolumn{2}{c}{ Kentucky bluegrass (Poa pratensis L.) } \\
A-34 & Warren's Turf Nursery, Ill, U.S.A. \\
Adelphi & New Jersey AES, U.S.A. \\
Baron & Barenburg Zaadhandel, N.V., Netherlands \\
Fylking & Swedish Plant Breeding Station, Sweden \\
Galaxy & New Jersey AES, U.S.A. \\
Glade & New Jersey AES, U.S.A. \\
Majestic & New Jersey AES, U.S.A. \\
Merion & United States Golf Association Green Section and Crops \\
& Research Division, ARS, USDA, U.S.A. \\
Park & Minnesota AES, U.S.A. \\
Pennstar & Pennsylvania AES, U.S.A. \\
Newport & Plant Materials Center (Washington), SCS, USDA, U.S.A. \\
Ram-1 & Wabhannet C.C., Maine, and United States Golf Association \\
& Green Section, U.S.A. \\
Sydsport & Weibullsholm Plant Breeding Institution, Sweden \\
Vantage & O.M. Scott Company, U.S.A. \\
Pr-9 & Experimental, USDA, U.S.A. \\
K-110 & Experimental, Pennsylvania AES, U.S.A. \\
K-150A & Experimental, Pennsylvania AES, U.S.A. \\
K-190 & Experimental, Pennsylvania AES, U.S.A. \\
K-213 & Experimental, Pennsylvania AES, U.S.A. \\
K.214 & Experimental, Pennsylvania AES, U.S.A. \\
K1-143 & Experimental, Northrup, King, and Company, Minn., U.S.A. \\
K3-162 & Experimental, Northrup, King, and Company, Minn., U.S.A. \\
& $\quad$ Perennial ryegrass (Lolium perenne L.) \\
Citation & New Jersey AES, U.S.A. \\
Diplomat & New Jersey AES, U.S.A. \\
Loretta & O. M. Scott Company, U.S.A. \\
Pennfine & Pennsylvania AES, U.S.A. \\
\multicolumn{2}{c}{ Annual bluegrass (Poa annua L.) } \\
Native selection from State College, Pennsylvania \\
\hline
\end{tabular}




\section{Screening of Growth Chamber Grown Grasses}

Three groups of grasses were started at different times in the greenhouses. When each group was 6 weeks old, the plants were thinned, fertilized with $37 \mathrm{mg} \mathrm{NH}{ }_{4} \mathrm{NO}_{3}$ per pot, brought to $26 \%$ soil moisture, and placed in a growth chamber set for a $27 / 16$ C day/night temperature regime with a 12 hour photoperiod $\left(\mu \mathrm{Em}^{-2} \mathrm{~s}^{-1}\right)$. The pots were maintained in the growth chamber for 4 weeks during which time they were allowed to dry to $11 \%$ soil moisture before rewatering. Twenty-four hours prior to the stress test, the pots within each replicate were brought to approximately the same weight. Following the stress test, plants were placed in the greenhouse for a 2 week recovery period, then they were washed of Jiffy-mix, dried at $70 \mathrm{C}$ for 24 hours, and weighed.

The first group of grasses consisted of four perennial ryegrass cultivars and Poa annua (six replications). This group was seeded on 2 May 1977 and tested on 12 July 1977. The average high and low temperatures for the recovery period for this group were 29.4 and $20 \mathrm{C}$, respectively. Results were based on observation of 1,500 plants.

The second group of grasses, consisting of 10 Kentucky bluegrass cultivars and Poa annua (five replications) was seeded on 31 May 1977 and tested on 2 Aug. 1977. The average high and low temperatures for the recovery period for this group were 27.7 and $20.5 \mathrm{C}$, respectively. Results were based on observation of 4,250 plants.

The third group of grasses consisted of 'Sydsport', and 'Penn. star' Kentucky bluegrasses, 'Pennfine' and 'Loretta ryegrasses, and Poa annua (three replications). This group was seeded on 21 June 1977 and tested on 29 Aug. 1977. The recovery period for this group was somewhat cooler than for the other two groups. The average high and low temperatures were 24.4 and 14.4 C, respectively. Results were based on observations of 750 plants.

\section{Carbohydrate Reserves and Mineral Analyses}

Plants of Sydsport, Pennstar, Pennfine, Loretta, and Poa annua were heated to $27,43,45,47$, and $49 \mathrm{C}$. After heating, they were immersed in liquid $\mathrm{N}$, lyophilized, and ground through a 20-mesh screen in a Wiley mill. Carbohydrates were extracted with $0.01(\mathrm{NH})_{2} \mathrm{SO}_{\text {, for }} 60 \mathrm{~min}$ in a $100 \mathrm{C}$ water bath and anal yzed by the method of Morris (1948) using anthrone. Additional plants were taken from several pots of each cultivar and im-

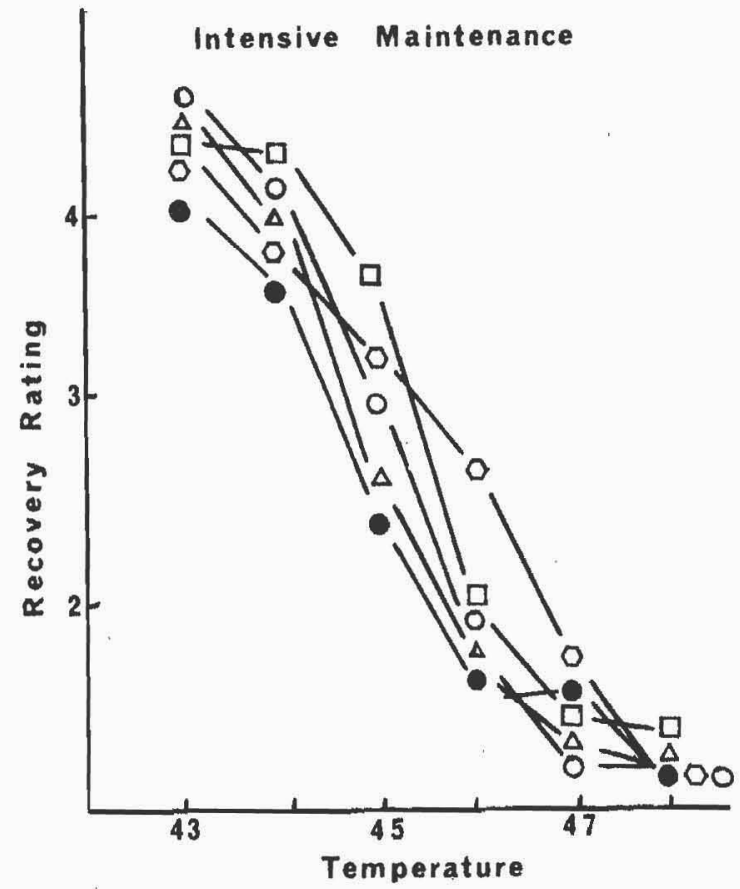

mersed in liquid $\mathrm{N}$, lyophilized, and ground through a 40-mesh screen in a Wiley mill for mineral composition analyses. Nitrogen was determined on an Autoanalyzer after micro-Kjeldahl digestion. The other elements are determined by standard plant analysis techniques.

\section{RESULTS AND DISCUSSION}

\section{N and Water Study}

Plants receiving the high level of $N$ and water (intensive maintenance) were less heat tolerant than those receiving the low level of $\mathrm{N}$ and water (low maintenance) (Fig. 1). Recovery ratings for the intensive maintenance group averaged 3.1 at $45 \mathrm{C}$ whereas ratings for the low maintenance group did not drop that low until the temperature was raised to $47 \mathrm{C}$.

Under intensive maintenance, Poa annua showed the same level of heat tolerance as the Kentucky bluegrass cultivars. However, Poa annua was significantly less heat tolerant than Kentucky bluegrass cultivars under low maintenance conditions. The cultivar by temperature interaction was not significant for the intensive maintenance group even though the cultivars changed rank between 45 and $46 \mathrm{C}$ (Fig: 1). Maximum separation (differentiation) among cultivars occurred from 45 to $46 \mathrm{C}$ for the intensive maintenance group and at $47 \mathrm{C}$ for the low maintenance group. At $47 \mathrm{C}$, there was a significant interaction for the low maintenance group which can be attributed to the sharp drop in recovery rating for Poa annua. This sharp drop was expected at some point and illustrated that differences in heat tolerance among the two species were manifest only under low maintenance conditions. Poa annua is generally considered to be less heat tolerant than Kentucky bluegrass (Beard, 1973).

The results of this study concur with those of Carroll (1943) and Julander (1945) concerning the in-

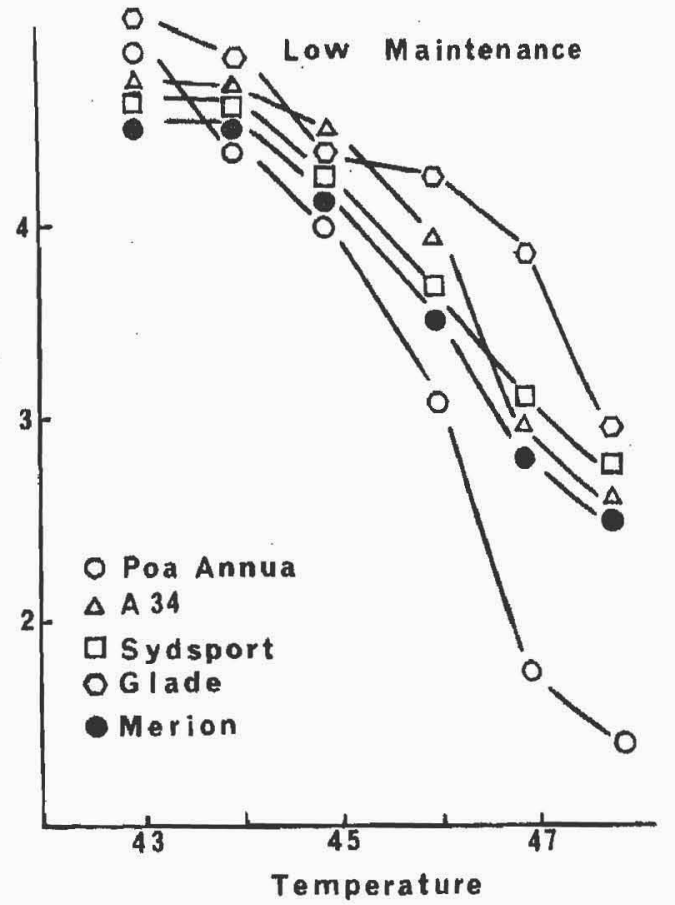

Fig. 1. Recovery rating versus temperature for intensive and low maintenance groups (Kentucky bluegrass and Poa annua), Rating scale, $1=$ dead, $5=$ no injury. 
fluence of $\mathrm{N}$ and water management on heat tolerance. They used field grown material and applied the heat stress in a different manner. In the tests reported here, the low maintenance conditions were used to grow plants for the experiments that follow because of the separation shown in Fig. 1.

\section{Greenhouse Screening Test}

Recovery ratings for Kentucky bluegrass cultivars in Set I showed a gradual decrease in heat tolerance from 'Vantage' to Kl-143 (Table 2). In Set II, the range from highest to lowest heat tolerance was from Sydsport to K-213. The cultivar by temperature interaction was not significant for either set, indicating that the bluegrasses showed parallel declines in recovery ratings over the entire temperature range. No cultivar was injured at a temperature significantly lower than that which injured the majority. Also, all cultivar averages were in the same part of the rating scale, between 3.0 and 4.0. The differences between cultivars, although statistically significant, were not nearly as great (appearance of the plants) as those between the high and low maintenance group or those between Poa annua and the Kentucky bluegrasses reported in the previous section. For these reasons, the bluegrasses were considered similar in heat tolerance. However, since Pennstar ranked toward the bottom of both sets, it appeared to be somewhat less heat tolerant than the other cultivars.

Pennstar, Merion, and Vantage changed rankings between Set I and Set II. This may have been due to variability in plant material, differences in recovery environments, or some other factor. The recovery environment for Set II was slightly warmer than that for Set I (average high/low of 25.7/19 C for Set II versus 24.7/18.5 C for Set I).

In subsequent experiments, Poa annua was included for testing with each group of grasses to assist in the interpretation of differences in heat tolerance found amoung cultivars. Also, plants were washed of JiffyMix, dried, and weighed to provide a quantitative measure of recovery. The recovery period was shortened to 2 weeks because extensive root growth after

Table 2. Mean recovery ratings for 21 Kentucky bluegrasses grown in the greenhouse. Rating scale: $1=$ dead, $5=$ little or no injury. Means represent average of three replications, five plants per replication, over the temperature range 43 to $48 \mathrm{C}$.

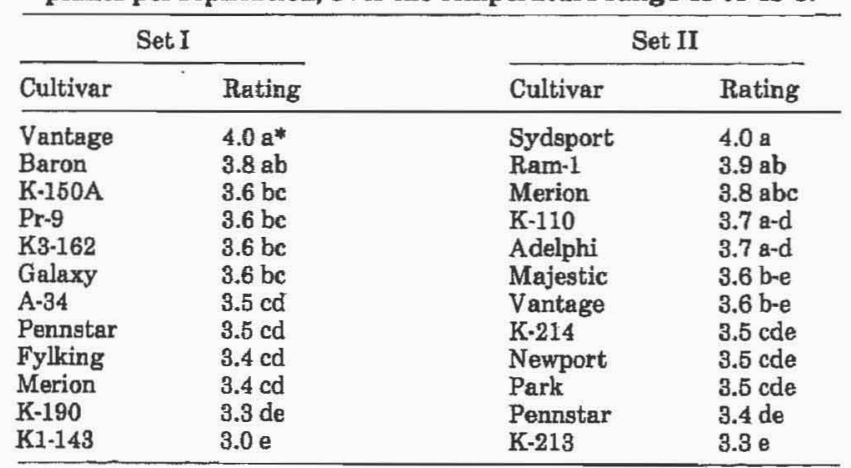

* Within columns, means having a letter in common are not different at the $\mathrm{k}=100$ level (5\% level of probability) by Duncan's Modified L.S.D. Test (Waller and Duncan, 1969).
4 weeks made it very difficult to wash the Jiffy Mix from the plants.

\section{Growth Chamber Screening Tests}

Plants used in this study were 10 weeks old, four of which were spent in the growth chamber to increase plant uniformity. The four ryegrasses and 10 bluegrasses were grown and tested as separate groups with Poa annua included with each. For each cultivar and treatment temperature, the dry weight of plants after recovery was expressed as a percentage of the weight of the control (recovery weight). Cultivar comparisons were made based on the average recovery weight over a given temperature range.

The Kentucky bluegrass cultivars as a group averaged $48 \%$ of the weight of their controls while $P O a$ annua averaged $28 \%$ over the range 42 to $47 \mathrm{C}$ (Table 3). In this test, Pennstar and Vantage were less heat tolerant than Newport, Sydsport, and Baron. The remaining cultivars were approximately equal in heat tolerance. The rankings of the growth chamber grown bluegrass differed somewhat from the results of the greenhouse screening. Vantage ranked lower and Newport ranked higher in this test than in the greenhouse test (Table 2 and 3). These changes may reflect differences in the greenhouse and growth chamber en. vironments. The relative differences among the Kentucky bluegrass cultivars were small. The cultivars were statistically split into five groups ("a" through "e", Table 3). 'Park,' the lowest cultivar receiving the letter "a", had a recovery weight of $49 \%$ while Penn. star, the highest cultivar receiving the letter "e", had a recovery weight of $43 \%$. Poa annua averaged 12 per. centage points below the lowest bluegrass cultivar. The spread among the cultivars was only half the mag. nitude of that between the genera when ratings were combined across all temperatures.

Some of the bluegrasses selected for testing were considered to be generally high (e.g. Sydsport) or low (e.g. Park) in turf quality as reported in the "Northeastern Regional Turfgrass Evaluation of Kentucky Blue. grasses (Poa pratensis L.) 1968 - 1973" (1977). These cultivars differed in turf quality throughout the region as well as at test areas where heat stress is a problem. Because the bluegrasses were approximately equal in heat tolerance, the differences in quality

Table 3. Recovery weights for 11 Kentucky bluegrasses and $P_{o a}$ annua grown in the growth chamber. Mean recovery weight (five replications) is for the temperature range 42 to $47 \mathrm{C}$,

\begin{tabular}{lc}
\hline Cultivar & Recovery wt $(\%) \dagger$ \\
\hline Newport & $53 \mathrm{a}^{*}$ \\
Sydsport & $51 \mathrm{ab}$ \\
Baron & $50 \mathrm{ab}$ \\
Ram-1 & $49 \mathrm{abc}$ \\
Park & $49 \mathrm{abc}$ \\
Merion & $48 \mathrm{bc}$ \\
Galaxy & $48 \mathrm{bc}$ \\
K-213 & $46 \mathrm{~cd}$ \\
Pennstar & $43 \mathrm{de}$ \\
Vantage & $40 \mathrm{e}$ \\
Poa annua & $28 \mathrm{f}$ \\
\hline
\end{tabular}

* Means having a letter in common are not different at the $\mathrm{k}=100$ level (5\% level of probability) by Duncan's Modified L.S.D. Test (Waller and Duncan, 1969). † Weight expressed as a percentage of the weight of the control. 
found in the field might be explained in one or more of the following ways: 1) the observed quality differences may have been due to factors other than heat tolerance such as drought or disease tolerance; 2) the results from screening tests of 10 -week-old, low $\mathrm{N}$ plants may not correlate well with heat tolerance in the field; 3) the heat tolerance of the cultivars may not be different but there are avoidance mechanisms operating in the field which reduce the tissue temperature of some cultivars more than others resulting in differential injury; 4) tolerance of indirect heat injury may be more important in influencing field quality; or, 5) the genotype make-up of the screening sample may have differed from that in the field plots. The dose-time relationships between injury and temperature may mean that the small differences in tolerance to direct heat injury translate into large differences in tolerance to indirect heat injury. The genotype problem could range from being minor with a cultivar like Newport which is $99 \%$ apomictic to being severe with a cultivar like Park which is made up of multiple selections.

With the ryegrasses, Loretta was significantly less heat tolerant than Pennfine, Diplomat, and Citation (Table 4). Poa annua was equal to the latter three ryegrasses in heat tolerances. There was 15 percentage point difference between Loretta and the other three rygrasses.

The ryegrasses selected for testing were cultivars which had differential summer performance at New Brunswick, New Jersey, a location where heat stress is a problem (C. R. Funk, personal communication).
These cultivars were similar in morphology and disease resistance and could be meaningfully compared. Field ratings for heat tolerance at New Brunswick decreased in the order Citation $>$ Diplomat, Pennfine> Loretta. The growth chamber screening test did not separate Diplomat, Pennfine, and Citation, but they all averaged above Loretta. (Table 4). The field rankings represent only one location and only four of the six cultivars were screened in both the field and growth chamber, so the comparison among experiments should be considered preliminary. The comparison indicates the potential of the screening test for identifying superior germplasm for heat tolerance. The validity of the screening test will be better judged as more information on ryegrass field performance becomes avail. able.

Sydsport, Pennstar, Pennfine, Poa annua, and Loretta, cultivars which ranked from high to low in heat

\begin{tabular}{|c|c|}
\hline Cultivar & Recovery wt $(\%) \dagger$ \\
\hline $\begin{array}{l}\text { Diplomat } \\
\text { Pennfine } \\
\text { Citation } \\
\text { Poa annua } \\
\text { Loretta }\end{array}$ & $\begin{array}{l}64 a^{*} \\
60 a \\
60 a \\
59 a \\
45 b\end{array}$ \\
\hline
\end{tabular}

* Means having a letter in common are not different at the $\mathrm{k}=100$ level ( $5 \%$ level of probability) by Duncan's Modified L.S.D. Test (Waller and Duncan, 1969). weight of the control.

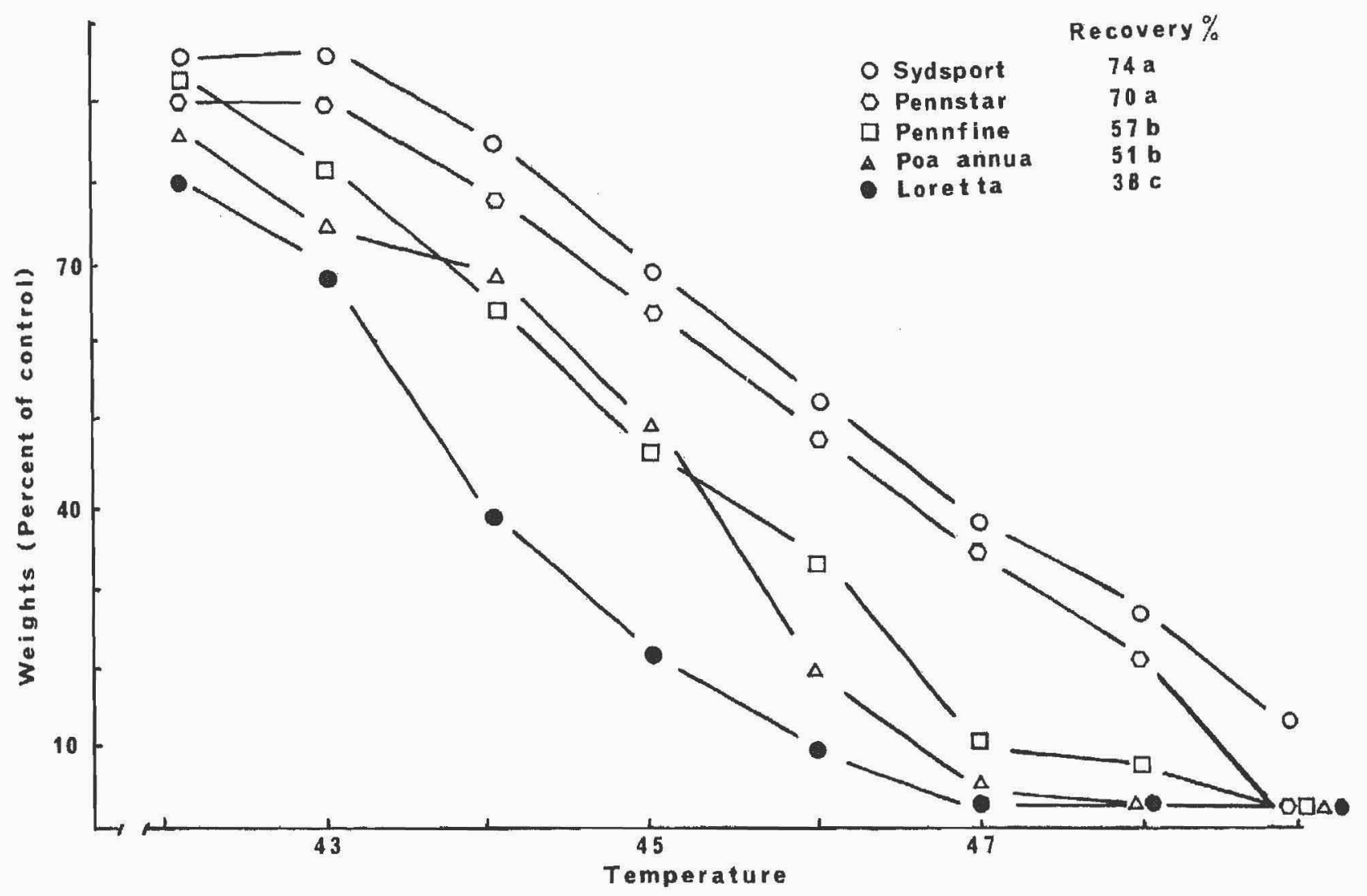

Fig. 2. Recovery weight versus temperature for Sydsport, Pennstar, Pennfine, Poa annua. 
Table 5. Mineral composition of five turfgrass cultivars and the correlation coefficient for recovery weight versus concentration of each element.

\begin{tabular}{|c|c|c|c|c|c|c|c|c|c|c|c|c|}
\hline Cultivar & $\mathrm{N}$ & $\mathbf{P}$ & $\mathrm{K}$ & $\mathrm{Ca}$ & $\mathbf{M g}$ & $\mathrm{Mn}$ & $\mathrm{Fe}$ & $\mathrm{Cu}$ & B & Al & $\mathrm{Zn}$ & $\mathrm{Na}$ \\
\hline & \multicolumn{5}{|c|}{$\longrightarrow \%$} & \multicolumn{7}{|c|}{-ppm- } \\
\hline (74) $¥$ Sydsport & 1.10 & 0.20 & 1.72 & 0.37 & 0.19 & 165 & 138 & 7 & 13 & 177 & 13 & 90 \\
\hline (70) Pennstar & 1.18 & 0.30 & 1.64 & 0.49 & 0.28 & 311 & 192 & 9 & 15 & 207 & 39 & 128 \\
\hline (57) Penrfine & 1.41 & 0.33 & 2.41 & 0.71 & 0.31 & 391 & 351 & 13 & 14 & 373 & 44 & 243 \\
\hline (51) Poa annua & 1.25 & 0.30 & 2.05 & 0.71 & 0.27 & 232 & 463 & 14 & 20 & 275 & 67 & 94 \\
\hline (38) Loretta & 1.41 & 0.35 & 2.21 & 0.46 & 0.25 & 364 & 479 & 12 & 18 & 550 & 61 & 144 \\
\hline $\mathbf{r}$ & -0.80 & -0.64 & -0.73 & -0.35 & -0.27 & -0.54 & $-0.96^{* *}$ & -0.77 & -0.74 & $-0.91 *$ & -0.87 & -0.22 \\
\hline
\end{tabular}

* Significant at the $5 \%$ level of probability.

** Significant at the $1 \%$ level of probability.

\$ Average recovery weight.

tolerance, were grown and tested as a group. Sydsport ranked highest in heat tolerance while Loretta ranked lowest (Fig. 2). Pennstar ranked lower than Sydsport but not statistically different. Rankings for $P o a$ annua, Pennfine, and Loretta concurred with earlier results (Table 4). The relative differences in response between Sydsport and Poa annua and Loretta, Poa annua, and Pennfine also agree with earlier tests. Sydsport recovery averaged 23 percentage points higher than Poa annua in earlier tests (Table 3) and 23 percentage points higher in this test (Fig. 2). Pennfine and Poa annua averaged 15 percentage points higher than Loretta previously (Table 4) and 19 and 15 percentage points higher, respectively, in this test. Finding large differences in heat tolerance was repeatable while small differences, e.g. between Pennstar and Sydsport, was not. Sydsport averaged 8 percentage points higher than Pennstar in one experiment (Table 3) and only 4 percentage points higher in this comparison (Sydsport not significantly different from Pennstar). The bluegrasses were again found to be similar in heat tolerance.

Pennstar and Sydsport sustained only slight injury at $43 \mathrm{C}$ while the other grasses suffered an 18 to $30 \%$ decline in recovery weight at this temperature. The variety by temperature interaction was not significant over the temperature range 42 to $47 \mathrm{C}$. Some of the plants of Loretta were killed when treated at $45 \mathrm{C}$. At $47 \mathrm{C}$, only Pennstar and Sydsport had 100\% survival.

\section{Carbohydrate Reserves and Mineral Analyses}

The carbohydrate levels for the cultivars were: Sydsport, 33.5\%; Pennstar, 29.2\%; Poa annua, $32.3 \%$; Pennfine, $28.4 \%$; and Loretta, $26.5 \%$. All five cultivars had high levels of energy reserves. There were no significant differences in carbohydrate Ievels between the plants heated at 27,43, 45, 47, and $49 \mathrm{C}$, so the values were averaged. Even though an increase in respiration rate would be expected between 27 and $43 \mathrm{C}$, the heating period was probably too short to cause a marked reduction in carbohydrates. The correlation coefficient $(r)$ between dilute acid extractable carbohydrate concentration and average recovery weight (data from Fig. 2) was 0.6 which was not significant at the $5 \%$ level. This implies a weak relationship between carbohydrate reserves and heat tolerance (when tolerance is measured by a $30 \mathrm{~min}$ exposure to high temperature). However, there may have been differences among the cultivars in the rate and efficiency of utilization of the reserves for regrowth.

Tissue samples of the five cultivars were subjected to chemical analyses to evaluate the relationship between mineral composition and heat tolerance (Table 5). The correlation coefficient for average recovery weight versus concentration was calculated for each element. Significant correlations were found only for $\mathrm{Fe}$ and $\mathrm{Al}$. Since these plants were only grown under one fertility regime, and perennial ryegrass normally accumulates higher concentrations of most elements than bluegrass (Butler and Hodges, 1967), no definite conclusions can be drawn from the data. However, the relationship between $\mathrm{Fe}$ and $\mathrm{Al}$ concentration and heat tolerance may be worthy of further study.

The differences in heat tolerance rankings between Sydsport, Pennstar, Pennfine, Poa annua, and Loretta were not explained by any differences in carbohydrate reserves or mineral composition.

\section{LITERATURE CITED}

Baker, B. S., and G. A. Jung. 1968. Effect of environmental conditions on the growth of four perennial grasses. I. Response to controlled temperature. Agron. J. 60:155-158.

Beard, J. B. 1973, Turfgrass: Science and culture. Prentice. Hall, Englewood Cliffs, New Jersey.

Butler, J. D., and T. K. Hodges. 1967. Mineral composition of turfgrasses. Hortic. Sci. 2:62-63.

Carroll, J. C. 1943. Effects of drought, temperature, and nitrogen on turfgrasses. Plant Physiol. 18:19-36.

Julander, 0 . 1945. Drought resistance in range and pasture grasses. Plant Physiol. 20:573-599.

Kinbacher, E. J. 1963. Relative high-temperature resistance of winter oats at different relative humidities. Crop Sci. 2:466468.

Lange, O. L. 1965. The heat resistance of plants, its determination and variability. p. 395-405. In F. Eckhardt (ed.), Meth. odology of plant eco-physiology. Montpellier Symposium: Unesco, Paris.

Levitt, J. 1972. Responses of plants to environmental stress. Academic Press, New York.

Morris, D. L. 1948. Quantitative determination of carbohydrates with Dreywoods anthrone reagent. Science 107:254-255.

NE-57 Technical Committee. 1977. Northeastern regional eval. uation of Kentucky bluegrasses (Poa pratensis L.) 1968-1973. Pennsylvania Agric. Exp. Stn. Bull. 814.

Pellett, H. M., and E. C. Roberts. 1963. Effects of mineral nutrition on high temperature induced growth retardation of Kentucky bluegrass. Agron. J. 55:474-476.

Waller, R. A., and D. B. Duncan. 1969. A Bayes rule for the symmetric multiple comparisons problem. J. Am. Stat. Assoc. 64:1484-1503.

Watschke, T. L., R. E. Schmidt, E. V. Carson, and R. E. Blaser. 1972. Some metabolic phenomena of Kentucky bluegrass under high temperature. Crop Sci. 12:87-90. 